\title{
SH14 - La cooperación internacional y el desarrollo social de la Mancomunidad Gran Ciudad del Sur
}

\author{
Jennifer Marini \\ $\mathrm{TS} /$ \\ Universidad de San Carlos de Guatemala
}

\section{Resumen}

$\mathrm{E}$ 1 objetivo principal de este trabajo de tesis es evaluar la incidencia en el desarrollo social de los municipios que integran la Mancomunidad Gran Ciudad del Sur-MGCS-, derivado de la cooperación internacional, misma que impacta en el crecimiento económico, mejora educativa y seguridad social a través de la ejecución de proyectos; lo anterior, con la ayuda de la población. Se utilizó el enfoque mixto, como un proceso para recolectar, analizar y vincular datos cualitativos y cuantitativos, a fin de obtener una perspectiva más precisa de la investigación, considerar diversas fuentes y tipos de datos. El instrumento utilizado fue la entrevista semiestructurada. Como resultado, se obtuvo información de las gestiones que se hacen para la aprobación de préstamos y donación del Banco Mundial, Banco Internacional de Desarrollo, entre otras agencias de cooperación internacional para financiar proyectos que contribuyen al desarrollo social de los municipios, determinando estadísticamente el porcentaje de su crecimiento en los indicadores de salud, educación, economía, seguridad, medio ambiente; en los últimos seis años. La investigación permite concluir que derivado de la poca capacidad financiera por parte de los gobiernos locales de la MGCS, la gestión que realiza se realiza desde la Mancomunidad ante la cooperación internacional, beneficia la ejecución de proyectos sociales que son importantes para elevar los niveles de desarrollo social en los municipios, considerando que estos están en desiguales condiciones de desarrollo humano, lo que genera dependencia para los países en vías de desarrollo como Guatemala.

Palabras clave: cooperación internacional, desarrollo social, dependencia

\section{Abstract}

$\mathrm{T}$ he main objective of this thesis work is to assess the impact on the social development of the municipalities that make up the Commonwealth big city of Sur - MGCS-, derived from same, international cooperation that impacts on economic growth, education and social security through the implementation of projects; the above, with the support of the population. Is used the approach mixed, as a process to collect, analyze and link data qualitative and quantitative, in order obtain a perspective more precise of the research, consider various sources and types of data. The instrument used was the interview semi-structured. As result, is obtained information of them steps that is make for the approval of loans and donation of the Bank world, Bank International of development, between other agencies of cooperation international to finance projects that contribute to the development social of them municipalities, determining statistically the percentage of its growth in them indicators of health, education, economy, security, environment; in the past six years. The investigation leads to the conclusion that derived from the limited financial capacity by local governments of the MGCS, the management is carried out from the Mancomunidad international cooperation, benefit the implementation of social projects that are important to raise levels of social development in the municipalities, whereas these are in unequal conditions of human development, which generates dependency to those countries in way of development as Guatemala. 